\title{
Influence of Spartina detritus enrichment on exchange of nutrients between sediment and water in an intertidal area of Bay of Fundy
}

\author{
Frede Østergaard Andersen* \\ Department of Fisheries and Oceans, Marine Ecology Laboratory, Bedford Institute of Oceanography, P.O. Box 1006, \\ Dartmouth, Nova Scotia B2Y 4A2, Canada
}

\begin{abstract}
The influence of Spartina alterniflora detritus on exchange of nitrate + nitrite, ammonia, and phosphate between sediment and water was studied after burial of plant litter in a muddy intertidal sediment in Cobequid Bay, Bay of Fundy. The enriched area in general showed higher flux rates than the control area. Dissolved inorganic nitrogen (DIN) flux was dominated by ammonium. Ammonium was normally only released from the sediment and maximum release rates were 300 and $180 \mu \mathrm{mol} \mathrm{NH}{ }_{4}^{+}-\mathrm{N} \mathrm{m}^{-2} \mathrm{~h}^{-1}$ in the enriched and control plot, respectively. In contrast, both uptake and release of nitrate + nitrite by the sediment was found; maximum uptake rates were 43 and 25 and release rates 98 and $51 \mu \mathrm{mol} \mathrm{NO}-\mathrm{NO}_{2}^{-} \mathrm{N} \mathrm{m}^{-2} \mathrm{~h}^{-1}$ in the enriched and control plot, respectively. Very low phosphate fluxes were observed in both plots. Initial $\mathrm{C} / \mathrm{N}$ and $\mathrm{C} / \mathrm{P}$ ratios of the Spartina material were $24: 1$ and $117: 1$, respectively. The $\mathrm{C} / \mathrm{N}$ ratio showed an initial decrease followed by a slow increase. The $\mathrm{C} / \mathrm{P}$ ratio showed the opposite pattern. Only $8.8 \%$ of the $\mathrm{N}$ and $2.7 \%$ of the P initially added to the sediment remained after 4 mo decomposition as Spartina material (>1 $1 \mathrm{~mm})$. The loss of $N$ and P was larger than the cumulated release of DIN and DIP to the overlying water; thus $33 \%$ of the N and $72 \%$ of the $P$ lost from the particulate detritus was retained in the sediment or lost in other ways. Flux rates of nitrate and ammonium in the enriched area were the only variables correlated. Exchange rates of nutrients were not correlated with in situ temperature. However, laboratory incubations at 7.5 and $17.5^{\circ} \mathrm{C}$ showed $Q_{10}$-values of up to 10 , indicating that short term changes of temperature in the field, e.g. diel variation, may be significant. The nutrient concentration of the water was low during the summer period and increasing during the fall.
\end{abstract}

\section{INTRODUCTION}

Many estuaries with extensive intertidal areas have a significant input of plant detritus from macrophytes. On the North American east coast salt-marshes dominated by Spartina alterniflora Loisel are especially important as detritus producers. Thus, Gordon et al. (1985) found that the primary production of $S$. alterniflora on low salt marshes may constitute $29 \%$ of total primary production in the upper reaches of the Bay of Fundy. Observations in the Bay of Fundy have shown that detritus originating from Spartina may be buried in the sediment at the location of growth or may be transported from the salt marshes by tidal currents and deposited elsewhere (Roberts 1982, Hargrave et al.

\footnotetext{
- Permanent address: Institute of Biology, Odense Univer-
} sity, Campusvej 55, DK-5230 Odense M, Denmark
1983, Schwinghamer et al. 1983). In a study on epibenthic algal production and benthic respiration on intertidal mudflats in the Bay of Fundy, Hargrave et al. (1983) found a negative net production indicating an import of organic matter which may be supplied by Spartina detritus.

Andersen \& Hargrave (1984) and Kepkay \& Andersen (1985) studied the effects of Spartina detritus enrichment on the aerobic/anaerobic benthic metabolism in sediments from the Bay of Fundy. Both studies showed increased metabolic rates as a result of detritus enrichment. Anaerobic processes predominated in the decomposition of the detritus and a zone with low redox potential developed around the detritus buried in the sediment.

The purpose of the present work was to study the regeneration of nutrients from sediments enriched with Spartina alterniflora detritus. The regeneration of 
nutrients and fluxes of gases at the sediment-water interface has often been compared to the typical elemental composition of organic matter mainly originating from phytoplankton in the sea as described by Redfield (1934) (Nixon et al. 1976, Boynton et al. 1982, Florek \& Rowe 1983). However, detritus derived from macrophytes may have a different elemental composition to planktonic detritus, which may influence the regeneration processes.

Non-living Spartina material was experimentally buried in an intertidal sediment in Cobequid Bay, Bay of Fundy. Fluxes of nitrate + nitrite, ammonium and phosphate in the enriched area were compared to those in an unenriched area. The variation of nutrient concentrations in the water at the study site was monitored and the importance of sediment nutrient regeneration on the concentration in the water column is considered. This study was carried out together with the study on benthic metabolism by Andersen \& Hargrave (1984).

\section{MATERIALS AND METHODS}

The study was carried out in an intertidal area located at Anthony Park on the southern shore of Cobequid Bay in the upper end of Bay of Fundy, Nova Scotia. Cobequid Bay has a large tidal range with a mean of 11.7 m near Anthony Park (Dalrymple et al. 1975). Intertidal sediments comprise $58.7 \%$ of the total area in Cobequid Bay (Prouse et al. unpubl.). The experimental site was flooded for about $4 \mathrm{~h}$ during each tidal cycle. For a further description of the study area see Hargrave (1978) and Hargrave et al. (1983). The experimental site in this study corresponds to Station 2 described in Hargrave (1978).

Above-ground living biomass of Spartina alterniflora was harvested on July 28, 1982 and gently rinsed with cold tap water. The plant material was cut into $1.5 \mathrm{~cm}$ pieces (to make later core-sampling possible) and dried at $60^{\circ} \mathrm{C}$ for $1 \mathrm{~d}$, and $400 \mathrm{~g} \mathrm{~m}^{-2}$ was buried on August 9, 1982, in the intertidal mudflat sediment just outside the lower edge of the Spartina zone. The upper $1.5 \mathrm{~cm}$ sediment was scraped away from a $1.5 \mathrm{~m}^{2}$ area, the Spartina material uniformly distributed in the plot $(+\mathrm{Sp})$, and finally the sediment replaced. Another 1.5 $\mathrm{m}^{2}$ area acting as a control $(-\mathrm{Sp})$ was treated in a similar way except that no Spartina was buried.

Plexiglass cores of undisturbed sediment with a diameter of $5.7 \mathrm{~cm}$ and a length of $11.5 \mathrm{~cm}$ were collected at intervals and brought to the laboratory $(1 \mathrm{~h}$ transport time). Measurements of fluxes across the sediment surface were carried out in the laboratory after careful replacement of the overlying water. The replacement water was filtered (Whatman GF/C) air- saturated sea water sampled simultaneously with the cores. At least 3 cores were taken from each area. All cores were closed with a plexiglass lid and sealed with silicon grease. A rotating magnetic bar attached to the underside of each lid slowly mixed the water during the incubation. The incubations were carried out at controlled temperatures close to those in the field at the time of sampling. Sediment temperature was determined with a shaded thermometer (precision $0.1 \mathrm{C}^{\circ}$ ), inserted to $1 \mathrm{~cm}$ depth between $1000 \mathrm{~h}$ and $1300 \mathrm{~h}$ on collection of cores when the mudflat was emerged.

Fluxes of nutrients were determined by measuring the concentrations in the water above the sediment in the cores at the beginning and end of a dark incubation period. Initial experiments showed that flux rates were constant during the applied short term incubations. Incubation times varied between $30 \mathrm{~min}$ and $5 \mathrm{~h}$ depending on temperature and oxygen uptake rate. Oxygen concentration did not fall below $80 \%$ of saturation. Concentrations of ammonium, nitrite, nitrate and phosphate were measured on a Technicon Auto Analyser II according to the manual.

The sediment in cores from $(+\mathrm{Sp})$ was sieved through a $1 \mathrm{~mm}$ sieve after the flux measurements and recognizable Spartina fragments above this size were recovered. The plant material was gently rinsed in deionized water and dried at $60^{\circ} \mathrm{C}$ for $1 \mathrm{~d}$. Organic carbon and nitrogen were determined on acidified (1N HCl) subsamples with a Perkin-Elmer 240 Elemental CHN Analyser.

Total phosphorus was measured as phosphate after combustion of subsamples $\left(550^{\circ} \mathrm{C}\right.$ for $\left.1 \mathrm{~d}\right)$ followed by dissolution of the phosphate contained in the ash in boiling $1 \mathrm{~N} \mathrm{HCl}$ (Andersen 1976).

\section{RESULTS}

\section{Nutrient concentrations}

The nitrate concentration in water covering the sediment at Anthony Park was low (0 to $4.9 \mu \mathrm{mol} \mathrm{l}^{-1}$ ) during late summer and showed the same mean as reported from another locality in the Bay of Fundy, Kingsport Marsh, for the period May through July (Walker et al. 1981) (Fig. 1). During late fall the nitrate concentration increased to $10 \mu \mathrm{mol} \mathrm{l}^{-1}$. The nitrite concentration was very low $\left(<0.5 \mu \mathrm{mol} \mathrm{l}^{-1}\right)$ during the whole investigation period. Both ammonium and phosphate (Fig. 1) showed a pattern similar to nitrate with increasing concentrations from October. The ratio (atomic proportions) between dissolved inorganic nitrogen (DIN) and dissolved inorganic phosphorus (DIP) in the water varied from 2 to 35 with an average of 14.7 $(\mathrm{SD}=8.5 ; \mathrm{n}=11)$. 


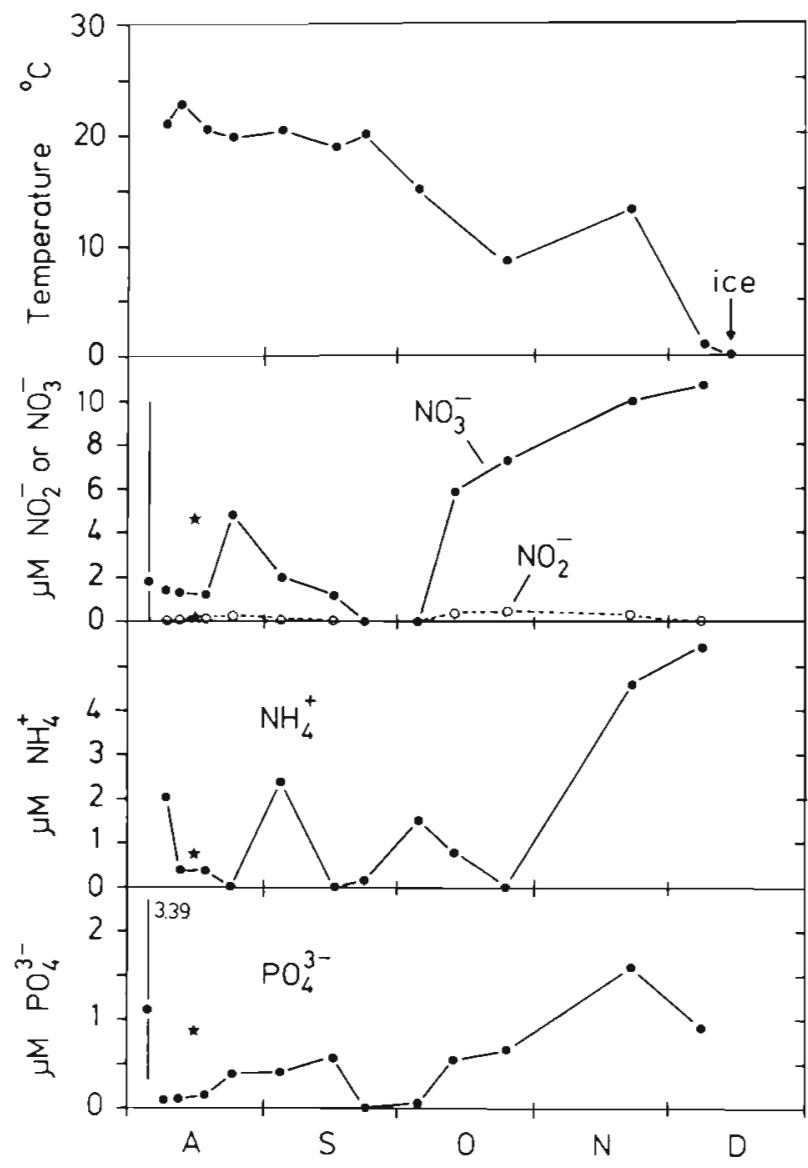

Fig. 1. Variation of sediment temperature and water concentration of nitrate, nitrite, ammonium and phosphate at Anthony Park, Aug to Dec 1982. Points and vertical lines on nitrate and phosphate figures indicate mean and range, respectively, of summer concentrations reported from Kingsport Marsh (Walker et al. 1981). Asterisks indicate mean values for Aug 1977 to 1980 from Cobequid Bay (P. D. Keizer pers. comm.)

\section{Sediment-water exchange of nutrients}

Fig. 2 shows the combined flux of nitrate and nitrite. The contribution of nitrite was less than $6.4 \%$ of the combined flux; for simplicity the flux of nitrate + nitrite will therefore be referred to as nitrate flux. Both uptake and release of nitrate from the sediment was observed. In late September to early October release of nitrate from the sediment was measured, whereas uptake was recorded during the rest of the period. The changes of flux rates over time were almost identical in the enriched and control plots. However, flux rates were usually higher in the enriched plot and apart from 1 measurement there was a net uptake of nitrate due to the Spartina calculated as $(+\mathrm{Sp})$ minus $(-\mathrm{Sp})$.

In contrast to nitrate, ammonium was in general released from the sediment (Fig. 3). The flux rates for

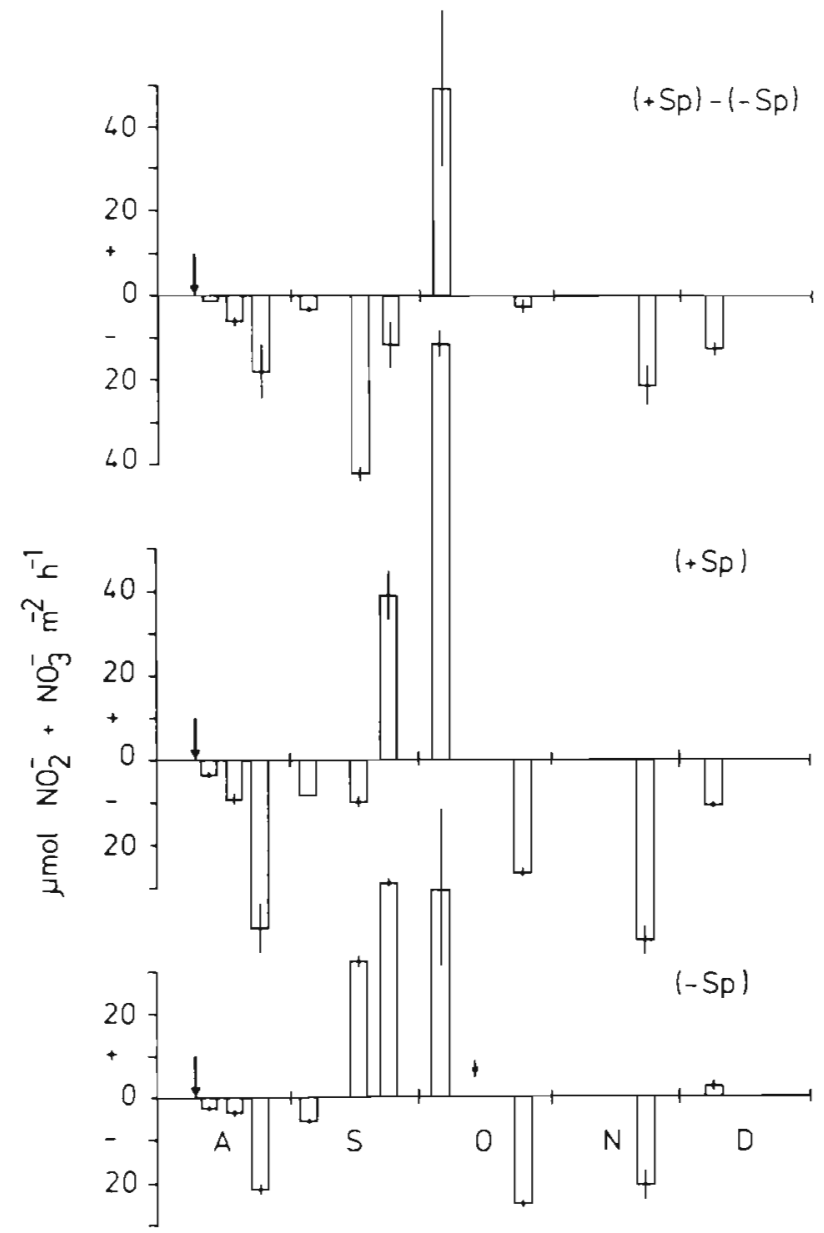

Fig. 2. Flux rates of nitrate + nitrite in the control plot $(-\mathrm{Sp})$ and in the Spartina enriched plot $(+\mathrm{Sp})$ at in situ temperature and the calculated difference $(+\mathrm{Sp})$ minus $(-\mathrm{Sp})$. Positive values indicate release from sediment, negative values indicate uptake. Mean values $\pm 1 \mathrm{SE}$. Arrow: date of burial of Spartina material. Point and vertical line in Oct indicates mean value $\pm 1 \mathrm{SE}$ measured on undisturbed mudflat sediment

ammonium usually were higher than those found for nitrate. In spite of large variation, a decreasing trend was apparent for the release of ammonium in the ( $-\mathrm{Sp}$ ) plot; however, there was no correlation between ammonium flux and in situ sediment temperature in the $(-\mathrm{Sp})$ plot. The temperature (Fig. 1) was relatively constant at about $20^{\circ} \mathrm{C}$ until late September, after which it decreased. The $(+\mathrm{Sp})$ plot showed low ammonium flux rates during the first month after burial of Spartina detritus, but thereafter higher flux rates were found. The net flux of ammonium due to the burial of Spartina (calculated as $(+\mathrm{Sp})$ minus $(-\mathrm{Sp})$ ) was negative immediately after the burial. From midAugust to the beginning of October, however, it showed an almost linear positive increase after which it decreased again. 


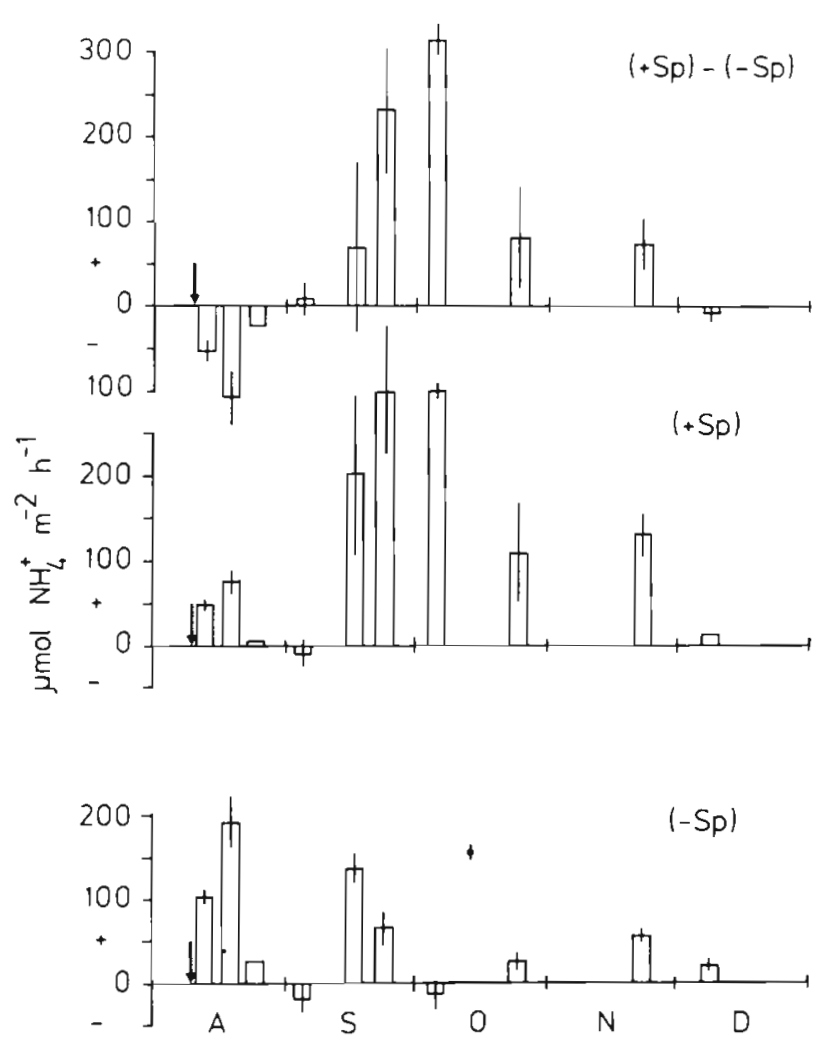

Fig. 3. Flux rates of ammonium at in situ temperature. See Fig. 2 for explanations

The phosphate flux (Fig. 4) was in general very low, except for an initial release of phosphate from the sediment in the enriched area. Cumulated fluxes of DIN and DIP over the 4 mo investigation period are calculated in Table 1 . There was a net release of both DIN (3.63 $\left.\mathrm{g} \mathrm{N} \mathrm{m}^{-2}\right)$ and DIP $\left(0.334 \mathrm{~g} \mathrm{P} \mathrm{m}^{-2}\right)$ due to the burial of Spartina detritus.

A correlation analysis of the flux rates of the nutrients showed that, except for nitrate and ammonium in the $(+\mathrm{Sp})$ area $(\mathrm{P}<0.05)$, none of the variables were correlated. Furthermore, nutrient flux rates were not correlated with the oxygen uptake or carbon dioxide release described by Andersen \& Hargrave (1984).

\section{Temperature effects of exchange rates}

The influence of short term changes of temperature on the nutrient flux was studied on 3 dates during the investigation period (Fig. 5). The cores were first incubated at $7.5^{\circ} \mathrm{C}$ and then at $17.5^{\circ} \mathrm{C}$ the following day. The effect of the increase in temperature was most evident for ammonium and highest in the $(+\mathrm{Sp})$ area with up to 10 times higher rates at the higher tempera-
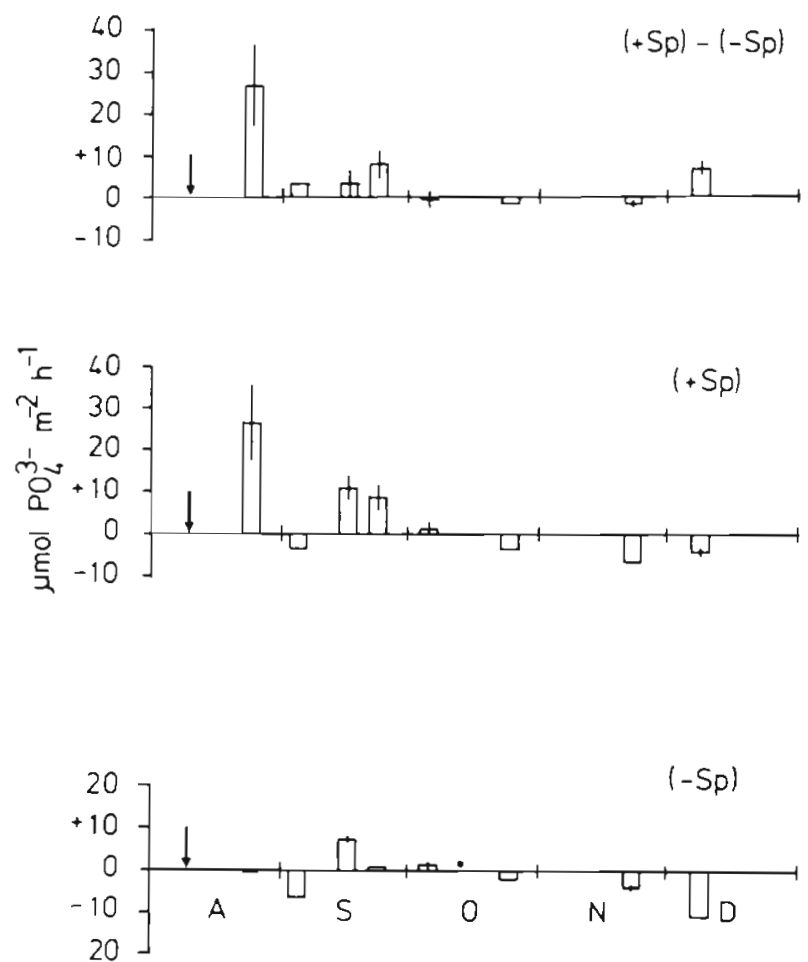

Fig. 4. Flux rates of phosphate at in situ temperature. See Fig. 2 for explanations

Table 1. Cumulated fluxes of DIN and DIP between sediment and overlying water during the period Aug 8 to Dec 11, 1982. $(+\mathrm{Sp})$ indicates the detritus enriched plot, $(-\mathrm{Sp})$ the control plot and $(+\mathrm{Sp})-(-\mathrm{Sp})$ the calculated net flux due to the burial of Spartina detritus. Calculations are based on mean values ( $\mathrm{n}=3$ to 6 ). Positive figures indicate release from the sediment and negative uptake

\begin{tabular}{|c|c|c|c|}
\hline & $(+S p)$ & $(-S p)$ & $(+S p)-(-S p)$ \\
\hline DIN flux $\mathrm{g} \mathrm{N} \mathrm{m}^{-2}$ & 5.38 & 1.75 & 3.63 \\
\hline DIP flux $\mathrm{g} \mathrm{P} \mathrm{m}^{-2}$ & 0.185 & -0.149 & 0.334 \\
\hline
\end{tabular}

ture. The pattern for temperature effect on nitrate flux was more complicated. In October the high temperature decreased nitrate uptake or caused nitrate release. In November and December, on the other hand, the high temperature increased the nitrate flux, especially increasing uptake in November by up to 4.8 times. The phosphate flux in October and December in the $(-\mathrm{Sp})$ plot was not significantly influenced by temperature, whereas the rest of the phosphate flux measurements showed higher rates at the high temperature.

In contrast to the effects of short term changes of temperature the nutrient flux rates were apparently not correlated with the in situ temperature. 
Fig. 5. Flux rates of nitrate + nitrite, ammonium and phosphate measured at $7.5^{\circ} \mathrm{C}$ (light columns) and $17.5^{\circ} \mathrm{C}$ (dark columns) on 3 different dates. Mean values $\pm 1 \mathrm{SE}$

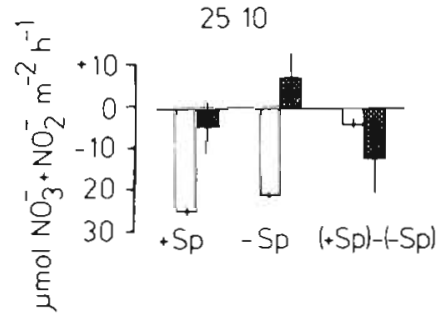

25. 10

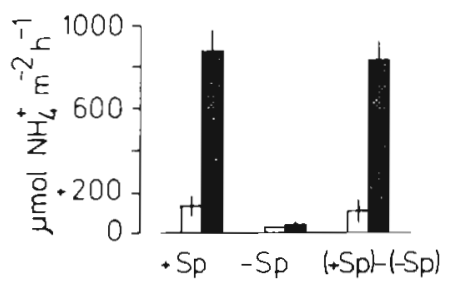

25. 10

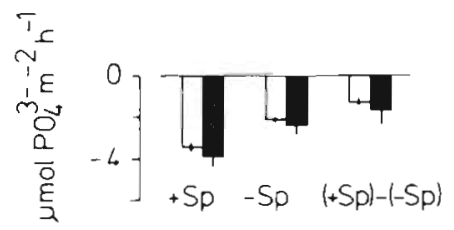

22. 11

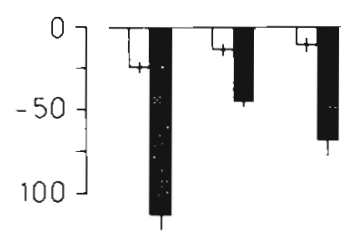

2211

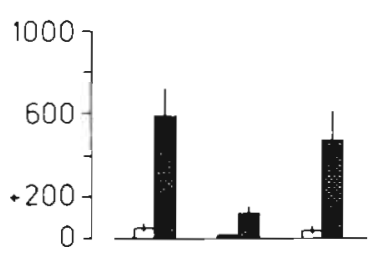

22. 11

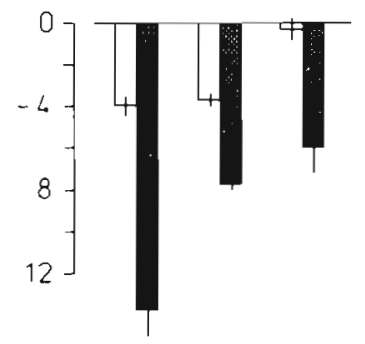

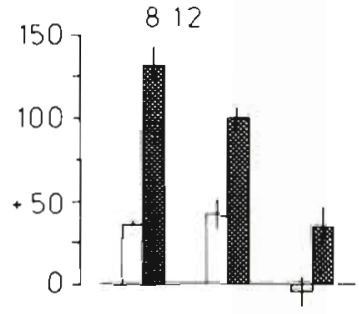

812
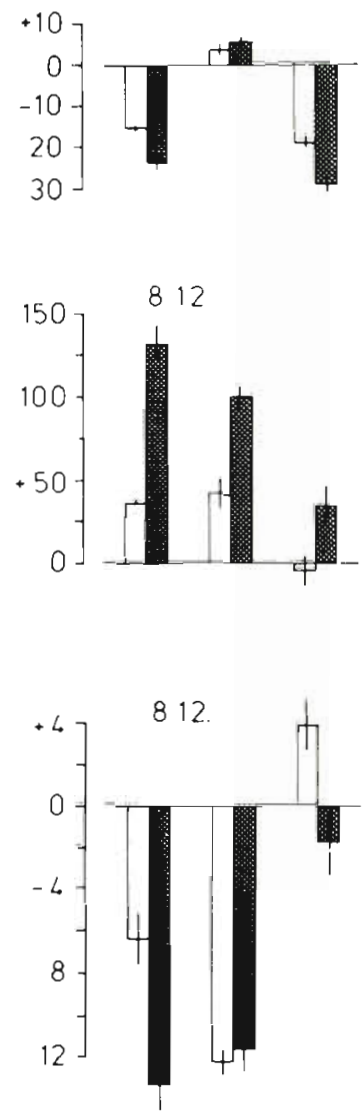

\section{Composition and loss of buried Spartina material}

The carbon and nitrogen percentages in the remaining Spartina particles in the sediment (Fig. 6) showed increases in the first month after burial followed by a slow decrease. The initial composition of the Spartina material buried was $43.0 \%$ carbon and $1.8 \%$ nitrogen, and the values reached after 4 mo decomposition were $48.1 \%$ carbon and $2.6 \%$ nitrogen, calculated as a percentage of ash free dry weight. The resulting $\mathrm{C} / \mathrm{N}$ ratio (Fig. 6) showed an initial drop from 23.9 to 18.0 and then a slow increasing trend, although the nitrogen figures created some fluctuation in the ratio. The phosphorus content exhibited a different pattern from carbon and nitrogen, with a rapid initial decrease in the phosphorus fraction of the organic matter from 0.37 to $0.09 \%$ followed by a linear increase to $0.14 \%$ during the remaining period (Fig. 6). The $\mathrm{C} / \mathrm{P}$ ratio increased initially from 117 to 509 and then decreased linearly to 336 (Fig. 6).

The relatively constant percentage dry weight composition of the Spartina does not reflect the large decrease in total organic content of the detritus over time. Andersen \& Hargrave (1984) calculated that

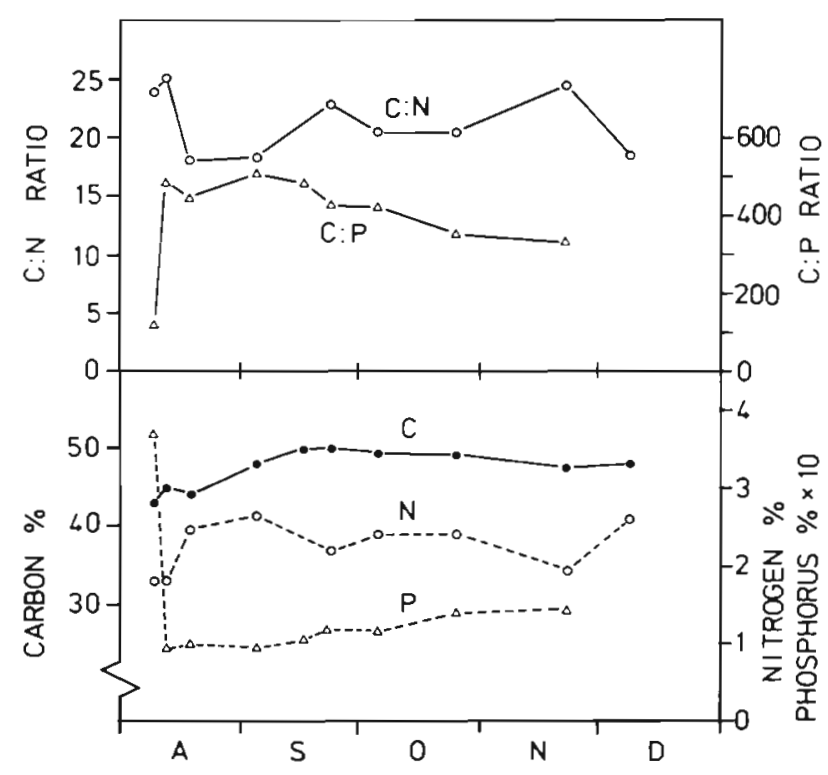

Fig. 6. Variation of carbon, nitrogen and phosphorus content in the remaining Spartina material. Mean values are shown. Deviations from the mean of duplicates were less than $5 \%$ for carbon and $10 \%$ for nitrogen. SD was less than $3 \%$ of the mean of phosphorus measurements ( $n=4$ to 6 ) 
$93.9 \%$ of the original particulate carbon ( $>1 \mathrm{~mm}$ ) buried was lost over $124 \mathrm{~d}$. The corresponding figures for nitrogen and phosphorus were 91.2 and $97.3 \%$, respectively (Table 2). A comparison showed that the cumulated loss of particulate nitrogen and phosphorus (> $1 \mathrm{~mm}$ ) over the 4 mo was larger than the cumulated release of DIN and DIP from the sediment surface (Table 2).

Table 2. Budget for particulate nitrogen and phosphorus (>1 mm) added to the sediment as Spartina detritus. Mean values are given $(\mathrm{n}=6)$

\begin{tabular}{|lcc|} 
& $\begin{array}{c}\text { Nitrogen } \\
\left(\mathrm{g} \mathrm{N} \mathrm{m}^{-2}\right)\end{array}$ & $\begin{array}{c}\text { Phosphorus } \\
\left(\mathrm{g} \mathrm{P} \mathrm{m}^{-2}\right)\end{array}$ \\
\hline Added to the sediment & 5.93 & 1.22 \\
Remaining after 4 mo & 0.52 & 0.033 \\
Loss of part. N or P & 5.41 & 1.19 \\
Fraction released from sed. & 0.67 & 0.28 \\
& & \\
- Ratio between released DIN or DIP from the sediment \\
(data from Table 1) and the loss of particulate $\mathrm{N}$ or P from \\
the detritus (>1 mm)
\end{tabular}

\section{DISCUSSION}

Most of the nitrogen ions released from the sediment were in the form of ammonium. This was also found by Nixon et al. (1976) in Narragansett Bay and by Henriksen et al. (1980) in experimental systems. Ammonium is produced by mineralization of organic matter and usually accumulates in the sediment creating a concentration gradient along which ammonium moves to the surface (Fenchel \& Blackburn 1979). Accordingly, the highest release rates were observed in the enriched area ( + Sp), with maximum rates of $300 \mu \mathrm{mol} \mathrm{NH}{ }_{4}^{+} \mathrm{m}^{-2}$ $\mathrm{h}^{-1}$, whereas the unenriched area $(-\mathrm{Sp})$ showed maximum rates of $180 \mu \mathrm{mol} \mathrm{NH}_{4}^{+} \mathrm{m}^{-2} \mathrm{~h}^{-1}$. Kemp et al. (1982) report release rates for ammonium from 10 to $280 \mu \mathrm{mol} \mathrm{m} \mathrm{m}^{-2} \mathrm{~h}^{-1}$ for 9 aquatic ecosystems.

Nixon et al. (1976) found a positive correlation between DIN flux (dominated by ammonium) and oxygen uptake. However, in the present study no such correlation was found. In a study by Davies (1975) a delay of about 1 mo between oxygen consumption and ammonium release was observed. This phenomenon was clearly observed in the $(+\mathrm{Sp}$ ) area where oxygen uptake increased rapidly and reached a plateau during the first week after burial of the Spartina material (Andersen \& Hargrave 1984), whereas ammonium showed a maximum release 1 mo after the detritus burial. The delay in ammonium release may be due to a binding to sediment particles of the ammonium initially produced (Fenchel \& Blackburn 1979, Rosenfeld 1979).
The nitrate flux was directed towards the sediment during the period late September to early October. Nitrate uptake rates in the present study (max. $43 \mu \mathrm{mol}$ $\mathrm{m}^{-2} \mathrm{~h}^{-1}$ ) were well below rates reported by Rutgers van der Loeff et al. (1981) and Kemp et al. (1982). There was a net efflux of nitrate from the sediment in September-October when the nitrate concentration in the overlying water was zero. A similar nitrate release was found by Kemp et al. (1982).

The phosphate flux was low in both plots, 27 and $11 \mu \mathrm{mol} \mathrm{m}^{-2} \mathrm{~h}^{-1}$ in $(+\mathrm{Sp})$ and $(-\mathrm{Sp})$, respectively. After mid-October only uptake of phosphate was observed. Low flux rates for phosphate have also been found in the Ems-Dollard estuary (Rutgers van der Loeff et al. 1981). The phosphate flux in $(+\mathrm{Sp})$ showed the highest release $2 \mathrm{wk}$ after detritus burial. This was probably due to phosphorus enrichment of the sediment through the addition of Spartina material as well as to the development of a low redox potential in $(+\mathrm{Sp})$ as shown by Andersen \& Hargrave (1984). Low redox potential increases the mobility of phosphate in the pore water (Bray et al. 1973, Watanabe \& Tsunogai 1984).

Short term changes of temperature had a considerable effect on flux rates. The significant effect of temperature on ammonium release in the enriched area $(+\mathrm{Sp})$ may be due to an increase in the mineralization rate of nitrogenous compounds originating from the Spartina detritus. The nitrate flux rate in the 2 plots did not increase with temperature in the October experiment as it did in November and December. The lower nitrate uptake in $(+\mathrm{Sp})$ and release in $(-\mathrm{Sp})$ may be caused by an oxidation of the increased amount of ammonium that is produced. The varying effect of temperature on the phosphate flux is difficult to interpret because the net transfer of phosphate from the water to the sediment may be a result of many processes and abiotic factors. The results from the short term experiments on temperature effects imply that the in situ flux rates may vary with diel variation in sediment temperature.

The nutrient flux rates were apparently not correlated with the seasonal temperature in the field. However, in situ temperature was measured on each sampling date. This means that other factors varying with time (e.g. aging of the buried detritus) may hide the effect of the seasonal variation in in situ temperature.

The decomposing Spartina material showed a decrease in the $\mathrm{C} / \mathrm{N}$ ratio during the first week, followed by a slow increase. The initial decrease was mainly due to an increase in nitrogen. Mann (1976) summarized data from a number of studies on nitrogen content of macrophytes during decomposition and found that in most cases there was an increase in the percentage nitrogen content, which was thought to be 
associated with the growth of microorganisms on the detritus particles. The percentage phosphorus content in the Spartina material decreased rapidly during the first $3 \mathrm{~d}$ after burial probably due to leaching. The subsequent increase in the phosphorus percentage is presumed to be due to sorption processes and microbial growth on the material.

Most of the total amounts of nitrogen and phosphorus initially added to the sediment through the Spartina material were lost from the particulate fraction (>1 mm) during the 4 mo of decomposition. Only a part of this loss was released as DIN and DIP to the water above the sediment. Thus, $33 \%$ of the nitrogen and $72 \%$ of the phosphorus lost from the particulate matter ( $>1 \mathrm{~mm}$ ) was retained in the sediment or lost as dissolved organic nitrogen or phosphorus. However, it should be emphasized that the flux rates of DIN and DIP were measured with a standard incubation that may not always be representative for the in situ conditions.

The cumulated flux of DIN due to the buried Spartina $((+\mathrm{Sp})$ minus $(-\mathrm{Sp}))$ was 10.9 times higher than the cumulated DIP flux. This is slightly lower than the average ratio between DIN and DIP concentration (14.7:1) found in the water covering the sediment at Anthony Park. The initial N/P ratio of the buried Spartina material was $4.9: 1$, thus, nitrogen is preferentially released from this experimentally enriched sediment. This is in contrast to Nixon et al. (1980) who found a relatively high release of DIP as compared to DIN in Narragansett Bay, probably due to denitrification.

The enrichment with Spartina detritus clearly increased the flux rates of inorganic nutrients from the sediments at Anthony Park. This implies that a higher organic load of the sediment, for example due to increases in primary production and sedimentation, will cause a higher regeneration. The flux rates measured in the control plot are probably representative of a natural mudflat sediment since redox potentials and sediment metabolism were similar in the 2 areas (Andersen \& Hargrave 1984). The direction of the flux is greatly influenced by the composition of the organic matter and by the redox conditions in the sediment. In this study only the net fluxes of DIN and phosphate over the sediment-water interface and changes in the composition of the remaining particulate organic matter in the sediment were investigated. Thus, the dynamics of the nutrients within the sediment after the liberation from the detritus complex and the importance of dissolved organic nitrogen compounds still have to be investigated.

Acknowledgements. I am grateful to the staff of Environmental Quality, MEL, for help during this work. I especially thank Dr B. T. Hargrave for generously offering laboratory facilities, for stimulating discussions and for improving the manuscript. This work was supported by grant no. 11-332 from the Danish Science Research Council.

\section{LITERATURE CITED}

Andersen, F. Ø., Hargrave, B. T (1984). Effects of Spartina detritus enrichment on aerobic/anaerobic benthic metabolism in an intertidal sediment. Mar. Ecol. Prog. Ser. 16: $161-171$

Andersen, J. M. (1976). An ignition method for determination of total phosphorus in lake sediments. Wat. Res. 10: 329-331

Boynton, W. R., Kemp, W. M., Keefe, C. W. (1982). A comparative analysis of nutrients and other factors influencing estuarine phytoplankton production. In: Kennedy, V.S. (ed.) Estuarine comparisons. Academic Press, New York, p. 69-90

Bray, J. T., Bricker, O. P., Troup, B. N. (1973). Phosphate in interstitial waters of anoxic sediments: Oxidation effects during sampling procedure. Science 180: 1362-1364

Dalrymple, R. W., Knight, R. J., Middleton, G. V. (1975). Intertidal sand bars in Cobequid Bay (Bay of Fundy). In: Cronin, L. E. (ed.) Estuarine research, Vol. 2. Academic Press, New York, p. 293-307

Davies, J. M. (1975). Energy flow through the benthos in a Scottish sea loch. Mar. Biol. 31: 353-362

Fenchel, T., Blackburn, T. H. (1979). Bacteria and mineral cycling. Academic Press, London

Florek, R. J., Rowe, G. T. (1983). Oxygen consumption and dissolved inorganic nutrient production in marine coastal and shelf sediments of the Middle Atlantic Bight. Int. Revue ges. Hydrobiol. 68: 73-112

Gordon, D. C. Jr., Cranford, P. J., Desplanque, C. (1985). Observations on the ecological importance of salt marshes in the Cumberland Basin, a macrotidal estuary in the Bay of Fundy, Estuar. coast. Shelf Sci. 20: 205-227

Hargrave, B. T (ed.) (1978). Geochemical and biological observations in intertidal sediments from Cobequid Bay, Bay of Fundy, Nova Scotia. Fish. Mar. Ser Tech. Rep. 782: $1-43$

Hargrave, B. T., Prouse, N. J., Phillips, G. A., Neame, P. A. (1983). Primary production and respiration in pelagic and benthic communities of two intertidal sites in the upper Bay of Fundy. Can. J. Fish. Aquat. Sci. (Suppl. 1) 40: 229-243

Henriksen, K., Hansen, J. I., Blackburn, T. H. (1980). The influence of benthic infauna on exchange rates of inorganic nitrogen between sediment and water. Ophelia (Suppl. 1): 249-256

Kemp, W. M., Wetzel, R. L., Boynton, W. R., E'Elia, C. F., Stevenson, J. C. (1982). Nitrogen cycling and estuarine interfaces: some current concepts and research directions. In: Kennedy, V. S. (ed.) Estuarine comparisons. Academic Press, New York, p. 209-230

Kepkay, P. E., Andersen, F. Ø. (1985). Aerobic and anaerobic metabolism of a sediment enriched with Spartina detritus. Mar. Ecol. Prog. Ser. 21: 153-161

Mann, K. H. (1976). Decomposition of marine macrophytes. In: Anderson, J. M., Macfadyen, A. (ed.) The role of terrestrial and aquatic organisms in decomposition processes. Blackwell Sci. Publ., Oxford, p. 247-267

Nixon, S. W., Oviatt, C. A., Hale, S. S. (1976). Nitrogen regeneration and the metabolism of coastal marine bottom communities. In: Anderson, J. M., Macfadyen, A. (ed.) The 
role of terrestrial and aquatic organisms in decomposition processes. Blackwell Sci. Publ., Oxford, p. 269-283

Nixon, S. W., Kelly, J. R., Furnas, B. N., Oviatt, C. A., Hale, S. S. (1980). Phosphorus regeneration and the metabolism of coastal marine bottom communities. In: Tenore, K. R., Coull, B. C. (ed.) Marine benthic dynamics. University of S. Carolina Press, Columbia, S.C., p. 219-242

Redfield, A. C. (1934): On the proportion of organic derivatives in sea water and their relation to their composition of plankton. In: James Johnson Memorial Volume, University Press, Liverpool, p. 176-192

Roberts, D. L. (1982). Distribution of organic carbon and nitrogen in various natural particle types of a fine intertidal sediment. M.Sc thesis, Dalhousie Univ.

Rosenfeld, J. K. (1979). Ammonium adsorption in nearshore anoxic sediments. Limnol. Oceanogr. 24: 356-364
Rutgers van der Loeff, M. M., van Es, F. B., Helder, W., de Vries, R. T. P. (1981). Sediment water exchanges of nutrients and oxygen on tidal flats in the Ems-Dollard Estuary. Neth. J. Sea Res. 15: 113-129

Schwinghamer, P., Tan, F. C., Gordon, D. C Jr. (1983). Stable carbon isotope studies on the Pecks Cove mudflat ecosystem in the Cumberland Basin, Bay of Fundy. Can. J. Fish Aquat. Sci. 40 (Suppl. 1): 262-272

Walker, A., Ackles, T., Perkyns, J., Mackinnon, M D., Keizer, P. D., McLachlan, J. (1981). The chemistry of tidal waters of a salt marsh of Minas Basin (Bay of Fundy), Kings County, Nova Scotia. Technical Report 29, Atlantic Research Laboratory, Halifax, Nova Scotia

Watanabe, Y., Tsunogai, S. (1984). Adsorption-desorption control of phosphate in anoxic sediment of a coastal sea, Funka Bay, Japan. Mar. Chem. 15: 71-83

This paper was submitted to the editor; it was accepted for printing on December 6, 1985 